\title{
PÄEVATEEMA
}

\section{TOIMETAJA PILGUGA KIRJANDUSKRIITIKAST, MITTE KULTUURIATAVISTLIKULT}

Nüüd on viis aastat sellest, kui Keeles ja Kirjanduses ilmus viimati pikk kriitikaülevaade. Kirjutas selle Jürgen Rooste. Ülevaates leiti, et „olemuslikult võib kirjanduskriitikat pidada kultuuriatavistlikuks ilminguks: otsest funktsiooni tal mälu hülgavas ja mittelugevas keskkonnas enam pole, aga et ta on olemas olnud, kunagi mingit rolli mänginud, siis ta ikkagi ilmutab end ajuti, kõlgub kuskil sääl". ${ }^{1}$ Kas just asi nii hullusti on, aga huvilisele võib toda lugu nüüdki lugeda soovitada: selguvad toona Rooste meelest levinumad kriitikatüübid, kriitikat avaldavad väljaanded, olulisemad arvustajad.

Viie aastaga ei muutu ju palju. Ühtteist aga siiski. Kas või see väide, et Eestis puuduvad Euroopa kirjanikud (tsiteeritakse Hannes Varblast) ja et eesti kirjandus on „üks väike ja väiklane, (oma) meestekeskne ja -vaheline asi", ${ }^{2}$ paneks pead vangutama praegu, mil eesti kirjandus on mitmekeelsem (ainult üks näide: Jaan Kaplinski) ja temaatiliselt mitmekesisem kui kunagi varem, mil kestab Andrus Kivirähki, Meelis Friedenthali, Kristiina Ehini ja Andrei Ivanovi rahvusvaheline tähelend. 2010. aastal tõdes Rooste ka, et „kogu kultuuriretseptsioon on meil üsna tõrjutud võrreldes näiteks spordiga", 3 ja avaldas nördimust selle

${ }^{1} \mathrm{~J}$. R o o s t e, Institutsionaliseeritud atavism. Märkmeid 2009. aasta eesti kirjanduskriitika kohta. - Keel ja Kirjandus 2010, nr 4 , lk 263.

${ }^{2} \mathrm{~J} . \mathrm{R}$ o o s t e, Institutsionaliseeritud atavism, lk 268.

${ }^{3}$ J. R o o s t e, Institutsionaliseeritud atavism, lk 263. üle, et Postimees saadab Arvamuse ja Kultuuri suvel kaheks kuuks puhkusele: „Kujutage nüüd ette olukorda, kui spordileheküljed paariks kuuks lihtsalt kaoks." ${ }^{4}$ Rooste ei osanud aga aimatagi, et AK edaspidi mitte ainult suvel ei puhka, vaid puhkuselt naastes mõnikord raamatuarvustusi ei avaldagi, püüdes seda kompenseerida raamatureklaamide leheküljega (see ilmub peaaegu alati), või siis eelistavad selle toimetajad defitsiitset arvustusteruumi omaenda teostele pühendada (nagu juhtus 1. novembril 2014). Lisandunud on küll Rein Veidemanni rubriik „Holograaf”, „milles kirjanikku ja tema loomingut portreteeritakse tervikpildis". Ka ei osanud Rooste aimata, et Eesti Päevaleht, mida võis pidada 2009. aastal „täiesti korralikuks kirjandusleheks", kuna lisaks reedesele Arkaadiale leiti kirjandusele palju ruumi ka nädalavahetuse kultuurilisas, ${ }^{5}$ paneb peagi Arkaadia kinni ja hakkab piirduma ühe lühemat sorti raamatuarvustusega nädalas. Nojah, vähemalt on see siis enamasti väärika raamatu sisukas arvustus. Kinni on aga ka ajakiri Lugu ja mandunud Eesti Ekspressi raamatuarvustuserubriik. Mis on juhtunud Varraku raamatublogiga, millesse tehti viimane sissekanne 7. septembril 2013 ? Veidi kompenseerib allakäigutendentse Eesti Rahvusringhäälingu 2013. aasta lõpus käima tõmmatud kultuuriportaali kirjandusrubriik, mis esialgu küll pea-

\footnotetext{
${ }^{4} \mathrm{~J} . \mathrm{R}$ o o s t e, Institutsionaliseeritud atavism, lk 264.

${ }^{5} \mathrm{~J}$. R o o s t e, Institutsionaliseeritud atavism, lk 274.
} 
miselt pressiteateid kollektsioneerib. Portaalilt loodaks edaspidi enamat, potentsiaali on. Aeg-ajalt jätab hea mulje Müürilehe kirjandusrubriik. Eks midagi ilmub mitmesugustes blogides ka. Jätkuvalt ei kahtle aga kirjanduskriitika vajalikkuses ja hoiavad arvustuste latti kindlalt kõrgel Looming, Vikerkaar, Keel ja Kirjandus, aina kaalukam Värske Rõhk ning tahaksin loota, et ka Sirp.

Millest see lati hoidmine sõltub, võib lugeja nüüd küsida. Kas toimetaja ei ole võimeline lehekülgi sisustama? Kaugeltki mitte, kaastööde puuduse üle toimetaja kurta ei saa ja küllap on selles teeneid muude lehtede kirjanduskriitikaruumi vähenemisel. Sirbi kirjanduskülgede kaasautorite seltskond on üpris lai ja kirev ning nende tööde tase seinast seina, mis tähendab, et sageli esineb häid arvustusi. Ka raamatuid, mis arvustamist väärivad, õnneks leidub, kaugelt rohkem kui häid arvustajaid, rääkimata leheruumist.

Toimetajale valmistab peavalu hoopis miski muu, üks üldisem tendents. Nimelt see, et kuigi kirjanduskriitikat loodetavasti siiski ei peeta lausa ussripiku- või karvapuhmasarnaseks atavistlikuks ilminguks, ${ }^{6}$ ei teata ometi, mis see siis on ja seetõttu ka, kuidas sellesse suhtuda. Lubatagu siinkohal tuua kaks tsitaati Sirbis 2005. aastal toonase kirjandustoimetaja Jan Kausi, kes üldse kriitikale kui sellisele tänuväärselt palju tähelepanu pööras, eestvedamisel läbi viidud kriitikagallupist: ${ }^{7}$

„Ma ei tea, mis see kirjanduskriitika on. Selle all ilmub jumala erinevat krunti asju. Lobast süsteemse kirjandusteadusliku analüüsini. Ja minu meelest ongi hea, et ilmub." (Peeter Sauter, kirjanik ja kriitik)

„Koolituse, mõistevõrguta või parasiitleva tundlemise jätan kriitika austa-

\footnotetext{
${ }^{6} \mathrm{~J} . \mathrm{R}$ o o s t e, Institutsionaliseeritud atavism, lk 263.

${ }^{7}$ J. K a u s jt, Gallup: kirjandus, kirjanik, kriitika ja kriitik. - Sirp 11. XI 2005.
}

va nimetuse alt välja. Mida tõeline kriitika kultuurile tähendab, peaks teada olema - ei ole tarvis sõnu raisata." (Arne Merilai, kirjanik, TÜ eesti kirjanduse professor)

Oi, kuidas pea kümme aastat hiljem tegelikult oleks vaja! Selge on ilmselt see, et arvustus langetab kirjandusteose suhtes hinnangu, ulatab lugejale abikäe ja annab autorile tagasisidet, aga mida see kultuurile tähendab? Kui see tähendab kultuuri enesemõtestamiseks ja identifitseerimiseks hädavajalikku refleksiooni, siis kui paljud kriitikud tajuvad oma seesugust vastutust? Kriitikat ei peaks sel juhul võrdlema mitte atavismide, vaid mõne anatoomiliselt hädavajaliku hämaralaga - ajuga või geenidega, mis organismi juhivad, aga mille toimimine on siiani enamjaolt mõistatus.

Küsimus on seda aktuaalsem, et kümne aastaga ei ole mitte ainult vähenenud kirjanduskriitikat avaldavate väljaannete ja nende lehekülgede arv, vaid on kasvanud uus põlvkond noori innukaid kriitikuid. Mõnevõrra muutunud kirjandusväljal on küsimus sellest, mis kriitikas toimub, jätkuvalt aktuaalne, uue kriitikute põlvkonna asjatundlik kasvatamine aga lausa hädavajalik. Selle väite illustreerimiseks veel üks tsitaat 2005. aasta gallupist:

„Kui selline murettekitav suund jätkub, võib kasvada peale uus põlvkond literaate, kes juhinduvad praegu levivast pealiskaudsest laadist kui normist. Õnneks on ka positiivseid tendentse." (Indrek Mesikepp, kirjanik, ajakirja Looming kriitikatoimetaja)

Ja üks teine, mis pärineb vaid paar nädalat enne gallupit ilmunud, praeguseks krestomaatilisest Märt Väljataga artiklist „Paar palvet retsensendile”:8

„Kahjuks on meil peaaegu täiesti kadunud seda sorti arvustus, mille kirjutamiseks loeb kriitik läbi kirjaniku kogu

${ }^{8} \mathrm{M}$. V ä lj a t a g a, Paar palvet retsensendile. - Sirp 28. X 2005. 
varasema toodangu ja asetab uue teose selle konteksti." Ning: „Mõistagi oleks hea, kui teos asetataks veel mitmesugusesse muussegi konteksti."

Pea samadele probleemidele osutati ka 2010. aasta gallupis ${ }^{9}$ ja küllap osutataks praegugi. Muidugi juhinduvad paljud uue põlvkonna kirjutajad pealiskaudsusest kui normist, kuid samamoodi kerkib igal aastal esile mitu andekat, laia silmaringiga ja süvenemisvõimelist kirjutajat. Millest aga nad kõik siiski näivad puudust tundvat, on n-ö kriitikakool. Ei ole ju eesti keeles ilmunud algajale arvustajale jõukohast õppematerjali, mis selgitaks kriitika olemust ja eesmärke, kui mitte arvestada Rein Veidemanni „Kriitikakunsti” (2000) ja T. S. Elioti „Valitud esseesid” (1997). Küllap ei ole päris kasutu ka tänavu Sirbis ilmunud „Kriitikakunsti” sari, millest tuleb eriti soovitada Aare Pilve „Kaasaloova kriitika hüpoteesi" ${ }^{10} \mathrm{~N}$-ö käsitööoskused tuleb aga omandada Märt Väljataga eelmainitud artikli abil ja muidugi lugedes, lugedes, lugedes teiste töid, üksi kirjutamist harjutades ja toimetajatelt tagasisidet oodates... Veidi parem

${ }^{9}$ J. Kau s, Kriitik(a) peab. Kriitik(a) võib. Kriitik(a) ei või. Kriitik(a) võiks. Jne. - Sirp 25. XI 2010. Selles gallupis tõstatati korduvalt veel kaks teemat: kriitikul võiks olla seisukohad ning napib tõlkekriitikat ja tõlkest rääkimise foorumeid. Viimast peaks aitama leevendada Eesti Kirjanike Liidu tõlkijate sektsiooni 2014. aastal loodud aastaraamat (õigupoolest ajakiri) „Tõlkija hääl”. Seni on ilmunud kaks numbrit.

${ }^{10} \mathrm{~A}$. P i l v, Kaasaloova kriitika hüpotees. - Sirp 21. XI 2014. on olukord ülikoolides: eesti kirjanduse magistrantide intiimses ringis toimuvad kriitikaseminarid, milles tutvustatakse kriitikateooriat, juhendaja käe all kirjutatakse ja tagasisidestatakse esimesi arvustusi, Tartus õpetatakse ka eesti kriitikalugu. Päris noortele kirjutajatele on ilmselt hea kool olnud „Ulakassi” arvustustevõistlus, mille kaastööde tase on aastatega aina tõusnud. ${ }^{11}$

Nojah, nüüd võib küsida, millal enne on kriitikule puust ette ja punaseks tehtud, mis see kriitika on, mida tõeline kriitika kultuurile tähendab ja kuidas seesugust kirjutada. Mis tahes kriitikakool ei suuda nagunii heastada silmaringi kitsust, vähest lugemust, süvenemissuutmatust ja kesist väljendusoskust tegeletagu pigem nende probleemidega. Ehk tasuks aga püüda retsensenti siiski aidata ja ehk ei ole päris tähtsuseta ka kriitika enese reflekteerimisvõime. Kirjutagem avaldamisruumi ahenemise kiuste rohkem mitte ainult kriitikat, millest jääbki võib-olla sedasi sõelale parem osa, vaid ka kriitikast.

PILLE-RIIN LARM

11 Üks üllatav ilming lausa n-ö varakevadise rohujuure tasandilt on kultuuriblogi „Kaktus” (kkaktus.wordpress.com) hiljutine sünd - sellegi algataja ja arvustajad on kõik alles koolinoored. 